\title{
Zika pela voz das mulheres
}

\section{Zika by women"s voice}

\section{Zika por la voz de las mujeres}

Mônica Mourão Lara Netto | monica.mourao@fiocruz.br

Fundação Oswaldo Cruz, Coordenadoria de Comunicação Social. Rio de Janeiro, RJ, Brasil.

\section{zikA}

Figura 1 - Zika

Palavras-chave: documentário; Zika; microcefalia; mulheres; direitos sexuais e reprodutivos; gestação; aborto.

Keywords: documentary; Zika; microcephaly; women; sexual and reproductive rights; pregnancy, abortion.

Palabras clave: documental; Zika; microcefalia; mujeres; derechos sexuales y reproductivos; embarazo; aborto. 
Contribuição dos autores: texto integralmente redigido pela autora.

Declaração de conflito de interesses: não há.

Fontes de financiamentos: não há.

Considerações éticas: não há.

Agradecimento/Contribuições adicionais:

Histórico do artigo: Submetido:12.ago.2016 | Aceito: 13.set.2016 | Publicado: 30.set.2016.

Apresentação anterior:

Licença CC BY-NC atribuição não comercial. Com essa licença é permitido acessar, baixar (download), copiar, imprimir, compartilhar, reutilizar e distribuir os artigos, desde que para uso não comercial e com a citação da fonte, conferindo os devidos créditos de autoria e menção à Reciis. Nesses casos, nenhuma permissão é necessária por parte dos autores ou dos editores.

O documentário Zika (2016), dirigido pela antropóloga e coordenadora da organização feminista nãogovernamental Anis - Instituto de Bioética, Debora Diniz, é um inquietante registro etnográfico de cinco gestantes moradoras da periferia e da zona rural paraibana infectadas pelo vírus Zika. A escolha do local não é aleatória: foi na Paraíba que Adriana Melo, médica que aparece no vídeo, correlacionou o patógeno e o surto de microcefalia. E é no Nordeste onde se concentra o maior número de casos confirmados de microcefalia em decorrência do Zika no Brasili.

A escolha de mulheres nordestinas pobres e da periferia é repleta de significados e (in)visibilidades. Primeiro, traz a reflexão sobre os determinantes sociais da epidemia do vírus Zika: as populações mais vulneráveis pela falta de acesso a serviços públicos diversos, como saneamento e educação, não seriam também as mais afetadas pelo vírus Zika? Outro ponto importante é conferir às mulheres o lugar de fala. No filme, a emergência sanitária global ${ }^{i i}$ não é narrada por médicos ou cientistas; o foco não são os números e índices, tampouco os mosquitos. Nele, mulheres que vivem na pele - e no ventre - o diagnóstico de microcefalia provocada pelo vírus Zika assumem o protagonismo do discurso. Permitir que compartilhem suas vivências e, sobretudo, dirigir a atenção aos seus silêncios, mais que sensibilizar o espectador, promove a reflexão sobre os direitos e as garantias a que elas têm (ou deveriam ter) acesso e cumpre o importante papel de visibilizá-las no debate público.

Quando essas mulheres saem do papel de apenas destinatárias dos discursos sobre a epidemia, produzidos pela mídia e pelos especialistas, e vão para frente das câmeras, suas narrativas ressoam a urgente necessidade de incluir centralmente, no debate de políticas públicas sobre o vírus Zika, políticas de saúde da mulher, em especial no que se refere aos direitos sexuais e reprodutivos, à informação e à comunicação.

A história de Alessandra, por exemplo, evidencia a expropriação e o controle do corpo feminino pelo Estado: ainda que seu feto comprovadamente possua malformações graves, o aborto não é uma opção $0^{i i i}$.

i O Ministério da Saúde informou em boletim que, até 13/07/2016, dos 1.687 casos confirmados de microcefalia, 86\% estão no Nordeste. A Paraíba é o terceiro estado com maior número de casos no país.

ii Em 01/02/2016, a Organização Mundial de Saúde (OMS) considerou o vírus Zika nas Américas e a sua possível associação ao surto de microcefalia no Brasil como uma Emergência de Saúde Pública de Importância Internacional (ESPII).

iii Segundo Pitanguy, enquanto em todo o mundo há visível avanço na flexibilização das condições para realizar um aborto seguro, inclusive em casos de malformação fetal, o Brasil segue como um dos países com a legislação mais rígida sobre o assunto. 
A mãe de quatro filhas e de Samuel, que possui microcefalia, cogitou interromper a gravidez ao descobrir a malformação do bebê, mas, além do desamparo legal para tanto, o marido a convenceu de que era desejo de Deus ter um filho com a síndrome.

Já Marina, mesmo gestando um bebê com malformações severas e raríssimas chances de sobrevivência, teve de prosseguir com a gravidez até estágio avançado, quando o grande volume de líquido amniótico, causado pela incapacidade de deglutir do feto, passou a lhe causar grande mal-estar.

Além da questão do aborto, o direito à informação sobre planejamento familiar e de acesso a métodos contraceptivos é outro ponto sutilmente levantado no filme quando Amanda, que realiza a terceira ultrassonografia da gestação, não sabe precisar a data da última menstruação. Segundo dados do Fundo de População das Nações Unidas (UNFPA/ONU), do total de nascimentos ocorridos nos últimos cinco anos, apenas 54\% foram planejados para aquele momento. O órgão afirma ainda que, no Brasil, a demanda não atendida por contraceptivos afeta cerca de 3,5 milhões a 4,2 milhões de mulheres em idade reprodutiva.

O documentário revela também quão precárias e desencontradas são as informações sobre a síndrome congênita do Zika. Adriana conta que, aos cinco meses de gestação, foi diagnosticado que o cérebro do bebê tinha preenchido somente metade do previsto no crânio. Embora tivesse ficado nervosa, a médica pediu que ela não se preocupasse, porque o quadro poderia se reverter. No vídeo, ela diz estar esperançosa: "creio que meu filho vai se desenvolver bem, vai estudar como as outras pessoas, normal, vai ter uma vida tranquila. E quando ele crescer, ele vai escolher o que ele quer ser, qual a profissão que ele quer ser". Adriana possivelmente desconhece que a microcefalia é somente um dos sintomas da síndrome congênita do vírus Zika, que afeta de forma grave e irreversível o sistema neurológico e pode estar vinculado a outros problemas, como danos cerebrais, convulsões, irritabilidade, rigidez muscular e dificuldades de visão e no sistema digestivo, segundo informações da Organização Mundial de Saúde (OMS).

Se essas mulheres não recebem informações adequadas sobre a sua saúde, tampouco podem contar com a assistência do Estado após o nascimento de seus filhos e filhas. Ana Angélica, percorre $85 \mathrm{~km}$ duas vezes por semana, para realizar a estimulação precoce da filha na capital. Para o trajeto, ela depende do carro da prefeitura que frequentemente tem problemas de abastecimento. Ela e o marido estão desempregados e esperam proteção social do Estado. Alessandra, moradora da periferia de Campina Grande, mãe de cinco filhos e esposa de um servente de pedreiro, também aguardava receber auxílio governamental.

As histórias de Alessandra, Marina, Amanda, Adriana e Ana Angélica evidenciam, portanto, a necessidade de as mulheres serem vistas como sujeitos plenos de direitos no contexto da epidemia do vírus Zika e, para tanto, devem ser ouvidas, devem ter suas vozes entendidas como capazes de produzir e legitimar o discurso sobre a emergência sanitária na mídiaiv.

\section{Referências}

1. $\quad$ Araújo IS, Cardoso JM. Comunicação e saúde [ebook]. Rio de Janeiro: Fiocruz; 2007 [citado em 2016 jul. 15].doi: http://dx.doi.org/10.7476/9788575413098.

2. Zika [Internet]. Direção de Debora Diniz. Assistente de Direção de Luciana Brito. Produção de Luciana Brito, Sinara Gumieri. Edição, montagem e finalização de Valesca Dios. São Paulo: Itinerante Filmes; 2016[acesso em 2016 jul. 15]. [29 min]. Disponível em: https://www.youtube.com/ watch?v=m8tOpS515dA.

iv Para a elaboração desta resenha, o livro "Comunicação e Saúde", de Inesita Araújo e Janine Miranda Cardoso, foi uma referência importante no sentido de apontar que para uma comunicação universal, no contexto do campo da Comunicação e Saúde, é necessário o exercício de descentralizar o lugar de fala, permitindo que a população possa ser não apenas destinatária dos discursos, como também interlocutora capaz de contribuir para os debates. Essa visibilidade dos atores e de suas demandas, para elas, é importante, sobretudo, para a formulação de políticas públicas. 
3. Hack J. Ministério da Saúde confirma 1.709 casos de microcefalia.In: Portal da Saúde, Boletim [Internet]. Brasília, DF: Ministério da Saúde, 2016 jul. [citado em 2016 jul. 22]. Disponível em: http:// portalsaude.saude.gov.br/index.php/cidadao/principal/agencia-saude/24625-ministerio-da-saudeconfirma-1-709-casos-de-microcefalia.

4. Nota do Ministério sobre declaração da OMS. In: Portal da Saúde, Zika/microcefalia [Internet]. Brasília, DF: Ministério da Saúde, 2016 fev. [citado em 2016 jul. 22]. Disponível em: http://portalsaude.saude. gov.br/index.php/cidadao/principal/agencia-saude/21975-nota-do-ministerio-sobre-declaracao-da-oms.

5. Almeida T. Quase metade das gestações no Brasil não é planejada, destaca Fundo de População da ONU. In: Organização das Nações Unidas no Brasil [Internet]. Brasília, 2016 jul. [citado em 2016 ago. 12]. Disponível em: https://nacoesunidas.org/quase-metade-das-gestacoes-no-brasil-nao-e-planejadadestaca-fundo-de-populacao-da-onu/.

6. Costello A, Dua T, Duran P, Gülmezoglu M, Oladapo OT, Perea W, et al. Defining the syndrome associated with congenital Zika virus infection. Bull World Health Organ [Internet]. 2016 Jun [cited 2016 Jul 22]1;94(6):406-406A. doi: 10.2471/BLT.16.176990.

7. Pitanguy, J. Os direitos reprodutivos das mulheres e a epidemia do Zika vírus. Cad. Saúde Pública [Internet]. 2016 jun. [citado em 22 jul. 2016]32(5):e00066016. doi: http://dx.doi.org/10.1590/0102$\underline{311 \times 00066016 .}$ 